Subscriber access provided by UNIV DI MILANO

Article

\title{
Combined chemical synthesis and tailored enzymatic elongation provide fully synthetic and conjugation-ready Neisseria meningitidis serogroup $X$ vaccine antigens
}

Davide Oldrini, Timm Fiebig, Maria Rosaria Romano, Daniela Proietti, Monika Berger, Marta Tontini, Riccardo De Ricco, Laura Santini, Laura Morelli, Luigi Lay, Rita Gerardy-Schahn, Francesco Berti, and Roberto Adamo

ACS Chem. Biol., Just Accepted Manuscript • DOI: 10.1021/acschembio.7b01057 • Publication Date (Web): 26 Feb 2018

Downloaded from http://pubs.acs.org on February 28, 2018

\section{Just Accepted}

"Just Accepted" manuscripts have been peer-reviewed and accepted for publication. They are posted online prior to technical editing, formatting for publication and author proofing. The American Chemical Society provides "Just Accepted" as a service to the research community to expedite the dissemination of scientific material as soon as possible after acceptance. "Just Accepted" manuscripts appear in full in PDF format accompanied by an HTML abstract. "Just Accepted" manuscripts have been fully peer reviewed, but should not be considered the official version of record. They are citable by the Digital Object Identifier (DOI®). "Just Accepted" is an optional service offered to authors. Therefore, the "Just Accepted" Web site may not include all articles that will be published in the journal. After a manuscript is technically edited and formatted, it will be removed from the "Just Accepted" Web site and published as an ASAP article. Note that technical editing may introduce minor changes to the manuscript text and/or graphics which could affect content, and all legal disclaimers and ethical guidelines that apply to the journal pertain. ACS cannot be held responsible for errors or consequences arising from the use of information contained in these "Just Accepted" manuscripts. 


\title{
Combined chemical synthesis and tailored enzymatic elongation provide fully synthetic and conjugation-ready Neisseria meningitidis serogroup X vaccine antigens
}

\author{
Davide Oldrini $^{\mathrm{a} \dagger}$, Timm Fiebig ${ }^{\mathrm{b} \dagger}$, Maria Rosaria Romano ${ }^{\mathrm{a}}$, Daniela Proietti ${ }^{\mathrm{a}}$, Monika Berger, ${ }^{\mathrm{b}}$ \\ Marta Tontini $^{\mathrm{a}}$, Riccardo De Ricco ${ }^{\mathrm{a}}$, Laura Santini ${ }^{\mathrm{a}}$, Laura Morelli ${ }^{\mathrm{c}}$, Luigi Lay ${ }^{\mathrm{c}}$, \\ Rita Gerardy-Schahn ${ }^{\mathrm{b}}$, Francesco Berti ${ }^{\mathrm{a}}$, Roberto Adamo*a \\ ${ }^{a}$ GSK, Via Fiorentina 1, 53100 Siena, Italy \\ ${ }^{b}$ Institute of Clinical Biochemistry, Hannover Medical School, 30625 Hannover, Germany \\ ${ }^{\mathrm{c}}$ University of Milan, Department of Chemistry, via Golgi 19, 20133, Milan, Italy \\ ${ }^{\dagger}$ These authors contributed equally to the study \\ "corresponding author: roberto.x.adamo@gsk.com \\ ${ }^{\ddagger}$ Present address: University of Milan, Department of Medical Biotechnology and Translational Medicine, \\ Via Saldini 50, 20133 Milan, Italy
}




\section{Abstract}

Studies on the polymerization mode of Neisseria meningitidis serogroup X capsular polymerase CsxA recently identified a truncated construct that can be immobilized and used for length controlled on-column production of oligosaccharides.

Here we combined the use of a synthetic acceptor bearing an appendix for carrier protein conjugation and the on-column process to a novel chemo-enzymatic strategy. After protein coupling of the size optimized oligosaccharide produced by the one-pot elongation procedure, we obtained a more homogeneous glycoconjugate compared to the one previously described starting from the natural polysaccharide. Mice immunized with the conjugated fully synthetic oligomer elicited functional antibodies comparable to controls immunized with the current benchmark MenX glycoconjugates prepared from the natural capsule polymer of or from fragments of it enzymatically elongated.

This pathogen-free technology allows the fast total in vitro construction of predefined bacterial polysaccharide fragments. Compared to conventional synthetic protocols, the procedure is more expeditious and drastically reduces the number of purification steps to achieve the oligomers. Furthermore, the presence of a linker for conjugation in the synthetic acceptor minimizes manipulations on the enzymatically produced glycan prior to protein conjugation. This approach enriches the methods for fast construction of complex bacterial carbohydrates. 


\section{Introduction}

Neisseria meningitidis (Men) is a Gram-negative bacterium responsible for bacterial meningitis and sepsis. Of the 12 different serogroups, the most common pathogenic strains are serotypes A, B, C, $\mathrm{W}$ and Y. Over the last 10 years, outbreaks of MenX occurred in Niger ${ }^{1}$, Uganda, Kenya ${ }^{2}$, Togo and Burkina $\mathrm{Faso}^{3}$, and rising incidence was also reported in America, Europe ${ }^{4}$ and China ${ }^{5}$. Monovalent carbohydrate-based vaccines to combat MenC infections and multivalent formulations targeting MenACWY serogroups have been licensed ${ }^{6}$, and proven to be cost-effective preventive therapies ${ }^{7}$. Although Men is diffused worldwide, a large prevalence is particularly observed in a region of SubSaharan Africa, the so called meningitis belt ${ }^{8}$. In major African epidemics, attack rates range from 100 to 800 per 100,000 population, but individual communities have reported rates as high as $1 \%$, caused almost entirely by serogroup $\mathrm{A}^{9}$. To decrease Men epidemics in Africa, in 2010 a MenA conjugate vaccine (MenAfriVac) was rolled out in a mass vaccination program in the meningitis belt ${ }^{10}$. While the introduction of MenAfriVac has substantially reduced the incidence of serogroup $\mathrm{A}$ infections, the occurrence of other serotypes, such as $\mathrm{C}, \mathrm{W}$ and $\mathrm{X}$ still remains relevant ${ }^{11}$. Increasing concern has also been raised by possible serogroup displacement, already described for $\mathrm{A}$ and $\mathrm{C}$ Men serogroups in China ${ }^{12,13}$. As a consequence, a clinical trial testing vaccination with a pentavalent MenACWXY Tetanus Toxoid-conjugate (including MenX) has been lately completed $^{14}$.

Additionally, over the last 5 years different reports have disclosed strategies for conjugation of MenX CPS related fragments. Micoli et al. ${ }^{15}$ identified proper bacterial growth conditions for the optimal production and release of MenX PS. A glycoconjugate vaccine was prepared by CPS hydrolysis with a final average degree of polymerization (avDP) of 15-20 repeating units, showing its effectiveness in protecting against MenX disease.

As an alternative to the polysaccharide isolation from pathogen cultures, chemically synthesized MenX oligomers with a maximal length of DP4 have been tested after coupling to a carrier $\operatorname{protein}^{16,17,18}$. However, the size of the oligomers was not sufficient to induce a proper immune response. In contrast, in vitro production of the MenX polymer by use of the recombinant MenX polymerase CsxA and introduction of this polymer (CPSX) into the established glycoconjugate production procedure, delivered a vaccine that in mouse immunization studies induced a robust immune response identical to the benchmark ${ }^{19}$. Importantly, in this earlier protocol the enzyme catalyzed synthesis of CPSX was started with acceptors obtained by hydrolysis of the natural polysaccharide. Similarly to the approach used for other meningococcal vaccines ${ }^{20}$, the polymer chains were then hydrolyzed, sized to a length of avDP10 and, after appropriate functionalization, conjugated to a carrier protein ${ }^{15,21}$. 
A

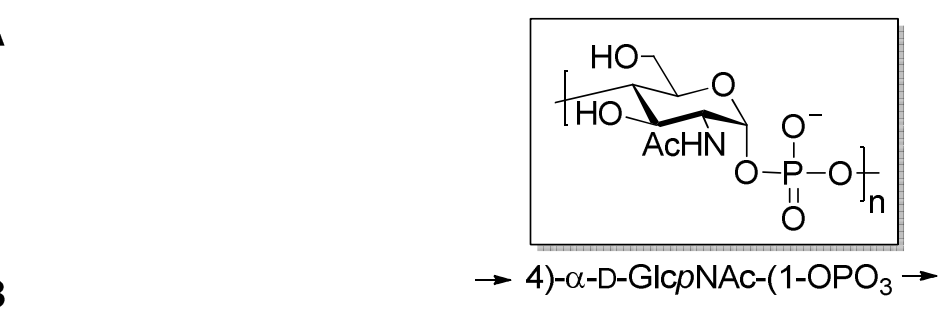

B

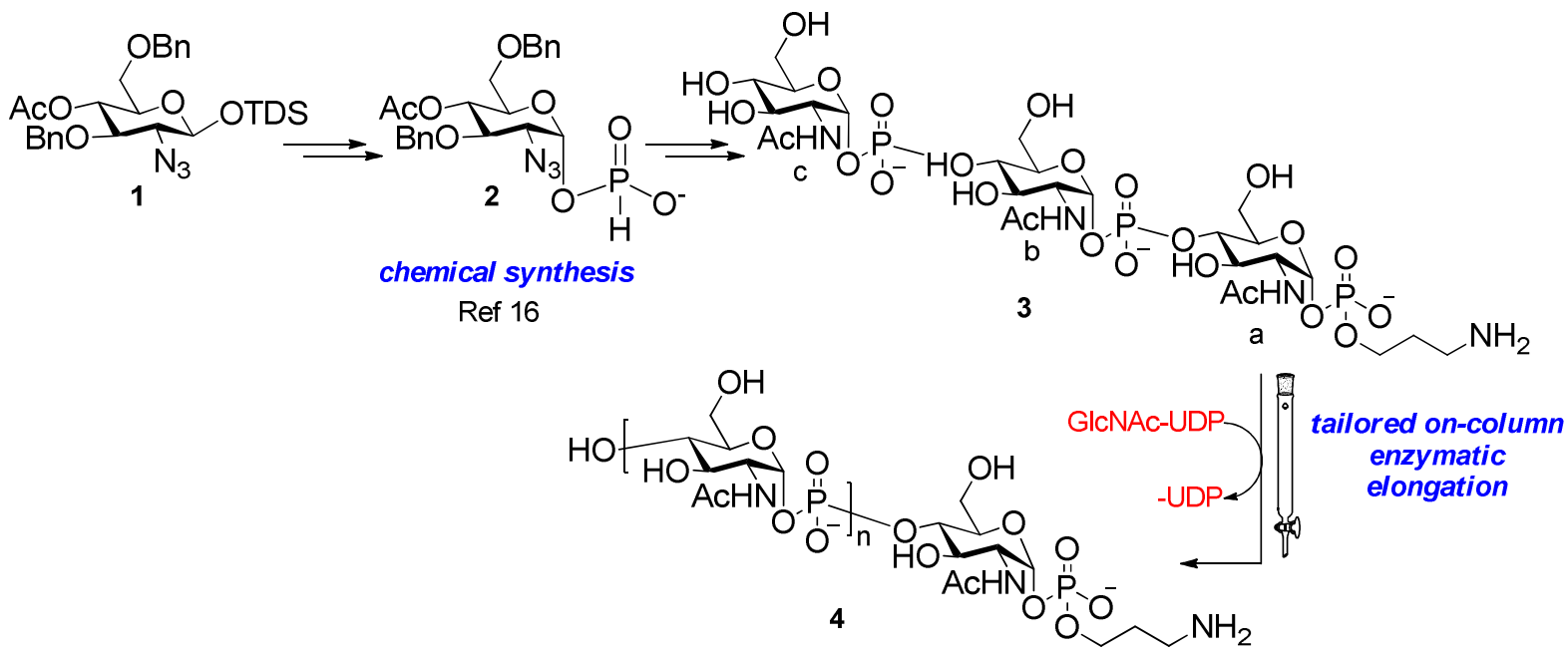

Figure 1. (A) Structure of the repeating unit of MenX capsule polysaccharide. (B) Proposed approach based on on-column elongation of a synthetic MenX trisaccharide acceptor ${ }^{16}$. TDS $=$ thexyldimethylsilyl. Letters a$\mathrm{b}$ in structure $\mathbf{3}$ are used for NMR assignments.

In the last decade, methods for accelerating the production of biologically relevant carbohydrates have encountered fast development ${ }^{22-25}$. The availability of in vitro prepared defined glycans is key for the production of glycoconjugates devoid of pathogenic contaminants, with higher standards for characterization and more robust correlation between structure and immune activity ${ }^{26}$. Approaches combining synthetic and enzymatic steps have also been successfully developed to get access to a large number of carbohydrates ${ }^{27}$. Despite chemo-enzymatic synthesis has found its major use for the synthesis of mammalian glycans ${ }^{28,29}$, examples are also reported for the production of complex bacterial sugars from Group B Streptococcus, Neisseria meningitidis and Shighella flexneri ${ }^{30-32}$. In this context, the use of heterologous bacterial enzymes has been exploited for the challenging incorporation of 1,2-cis linkages and $\alpha$-sialylation, since it offers indisputable advantages in the stereochemical control of the reaction compared to chemical methods. Bacterial enzymes have also been used to assemble mammalian glycans ${ }^{33}$. 
Here we describe a chemo-enzymatic approach based on the enzyme catalyzed one-pot elongation of a short synthetic MenX trisaccharide acceptor, bearing a chemical appendix already in place for conjugation. By use of a recently described distributive variant of the capsule polymerase $\mathrm{CsxA}^{34}$, we synthesized oligomers with predefined average length which were directly conjugated to the genetically detoxified diphtheria toxin $\mathrm{CRM}_{197}$. The enzyme was coupled to a solid-phase to facilitate downstream processing of the reaction mixture. The chemo-enzymatically made glycoconjugate was immunologically evaluated in comparison to a glycoconjugate prepared using a polysaccharide fraction isolated from bacterial culture.

\section{Results and Discussion}

\section{Chemical synthesis of MenX trisaccharide acceptor}

MenX capsular polysaccharide consists of $\mathrm{N}$-acetylglucosamine-4-phosphate residues held together by $\alpha-(1 \rightarrow 4)$ phosphodiester bonds (Figure $1 \mathrm{~A})$. Taking in consideration that the elongation cascade of CsxA polymerization was commenced in a previous report from a short acceptor with avDP $3.2^{19}$, we chemically synthesized the CPSX trisaccharide acceptor 3 (Figure 1B), as previously reported $^{16}$. Briefly, 2-azido-2-deoxy silyl glucoside 1 was prepared in multigram scale in 9 steps from D-glucosamine hydrochloride (18\% overall yield), and converted in two steps into the $\alpha$ hydrogenphosphonate 2, which was employed as key building block (Figure 1B). ${ }^{16}$ Elongation of intermediate 2 was carried out by iteration of a two-steps sequence, comprising pivaloyl chloridemediated hydrogenphosphonate coupling followed by Zemplén de-O-acetylation, to eventually afford trisaccharide 3 after global deprotection. On the whole acceptor 3 was obtained in 18 steps from D-glucosamine hydrochloride with a $0.3 \%$ overall yield, without taking into account that some intermediates could be recycled during the process ${ }^{16}$. NMR spectra of the trimer were in agreement with the published data ${ }^{16}$. The presence of a phosphodiester-linked amino propyl linker provides a chemical handle for coupling to a carrier $\operatorname{protein}^{15,35}$.

\section{N-terminus CsxA mapping and on-column attachment}

CsxA used for the production of long CPSX is able to elongate short CPSX fragments with an avDP of $\sim 3^{19}$. CsxA works following two different elongation mechanisms: in the initial phase of the reaction, short DPs are elongated through a distributive mechanism, and the nascent chain is released after each transfer until an intermediate chain length of $\sim$ DP 18 is reached. Subsequently, intermediate length fragments $(<\mathrm{DP} 18)$ bind to a separate binding site located in the C-terminus and are elongated in a processive manner, undergoing multiple rounds of monomer addition to reach the final polysaccharide length ${ }^{34}$. The interplay of the two mechanisms leads to skewed or even 
separated product pools when using CxsA and prevents the generation of oligosaccharides suitable for the generation of a glycoconjugate vaccine ${ }^{34}$.

Recently, a truncated version of CsxA was generated ( $\triangle \mathrm{C} 98-\mathrm{Csx} A)$ lacking the $\mathrm{C}$-terminal binding site and thus allowing tailored synthesis of oligosaccharides with a length suitable for glycoconjugate synthesis ${ }^{34}$. While $\Delta$ C98-CsxA was shown to elongate DP $>2$, it had not been investigated if the missing C-terminus changed the overall binding pattern of the oligosaccharide acceptors. Consequently, we first analyzed the binding of short acceptors (avDP6.5) to wild type CsxA in comparison to $\triangle \mathrm{C} 98$-CsxA.

Saturation Transfer Difference (STD) NMR experiments were undertaken in order to qualitatively map the average positions of the MenX oligomers closer to binding pockets of the two constructs. An evaluation of the STDD-NMR spectrum (STD-NMR with blank subtraction) of the complex formed by CsxA and the avDP of 6.5 fragments exhibited the strongest signal enhancement for H1, H-2 and H-4, followed by H-5 and the NHAc moiety and, with minor intensity, H-3 and H-6 (Figure 2A). This suggests that the attack of the GlcNAc-UDP donor to the hydroxyl at position 4 might occur from the bottom face of the oligomer. Most importantly, the same pattern of signals was observed between $\triangle$ C98-CsxA and the avDP6.5 mixture, with the only difference that the STD-NMR intensity was lower if compared to full-length CsxA, indicating a weaker binding to the tested oligomers, as expected for a distributive enzyme.

Following our main purpose to use the synthetic CPSX trimer as priming oligosaccharide for the enzymatic elongation, the interaction between this molecule and both CsxA constructs was mapped (Figure 2B). Again, the STD-NMR intensity in the presence of $\triangle \mathrm{C} 98$-CsxA was lower, but the binding pattern was comparable to CsxA and, most importantly, in good agreement to the overall binding epitope of the natural avDP6.5. As anticipated, no STD-NMR signal was recorded for the linker, demonstrating that it does not interact with the enzyme in a specific way. Interestingly, both constructs have contact to $\mathrm{H}-1 \mathrm{a}$ and $\mathrm{H}-1 \mathrm{~b}, \mathrm{c}$, demonstrating that CsxA is able to accommodate the synthetic trimer in its active site pocket and this interaction is not altered by the missing C-terminal binding site. Although we cannot exclude that a shorter fragment could bind to the enzyme, these findings confirmed that the synthetic trisaccharide was engaged by a C-terminally truncated CsxA construct with sufficient interaction for further elongation. A more in depth structural study of the interaction between the enzyme and different length oligomers will deserve further exploration. 


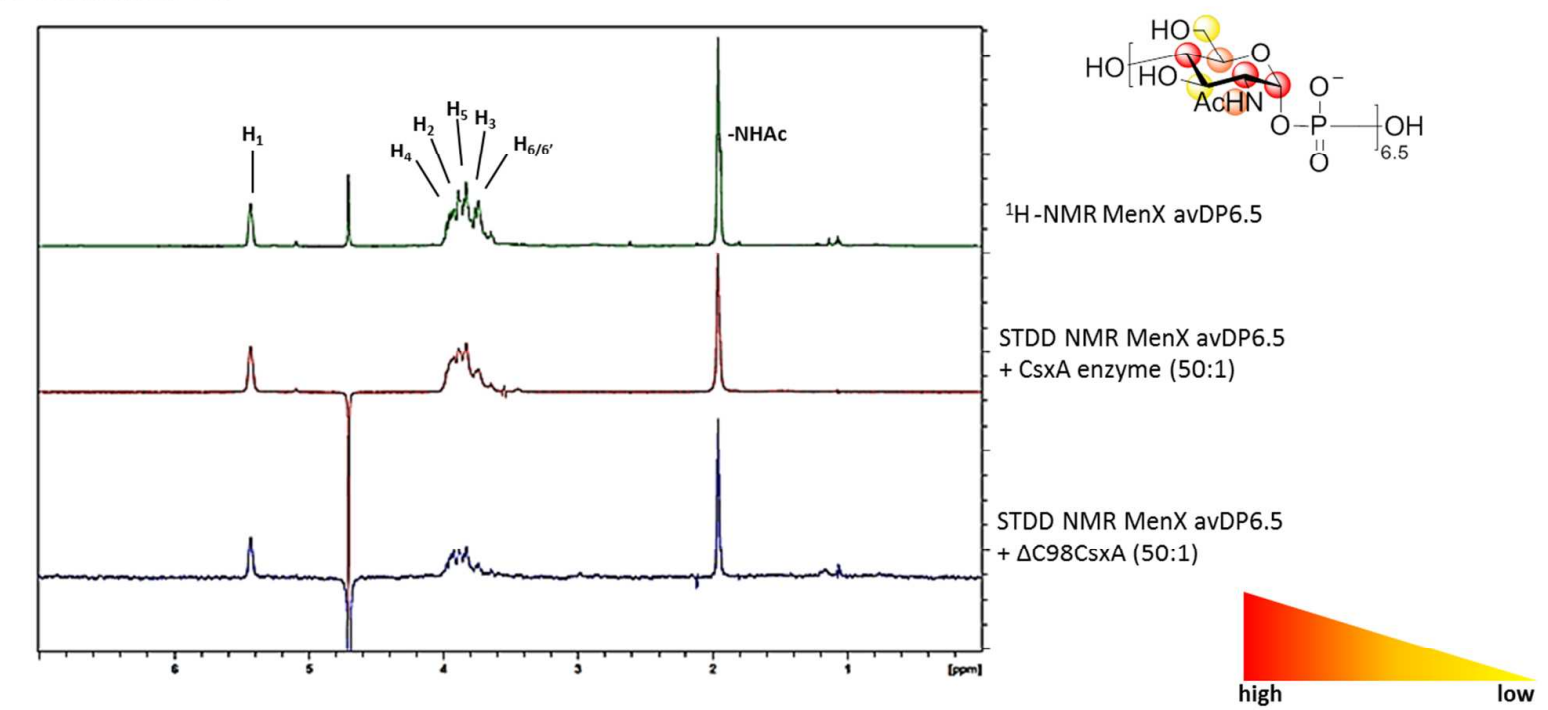

B MenX synthetic DP3

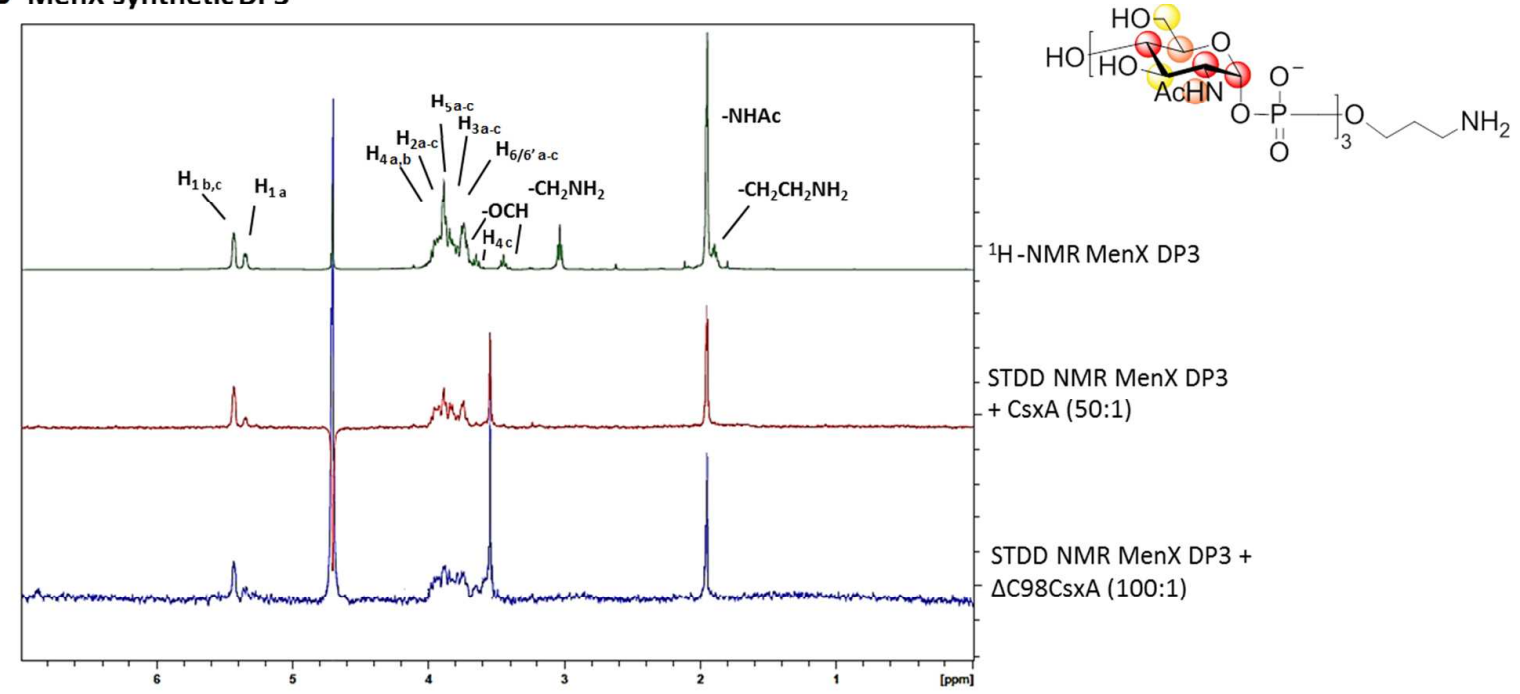

Figure 2. STDD-NMR spectra of the two MenX oligomers in complex with (A) full length CsxA and (B) truncated version $\triangle \mathrm{C} 98$-CsxA at the specified molar ratio. Chemical shifts of the linker (at 3.4, 3.8, 2.9 and 1.9 ppm) disappear at the STD NMR showing no engagement with the enzyme. 
a)

d)

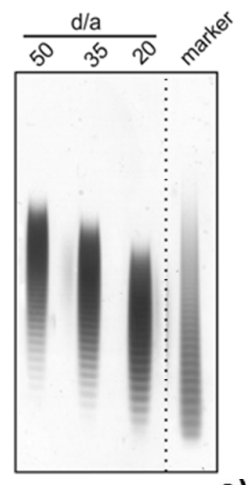

e)
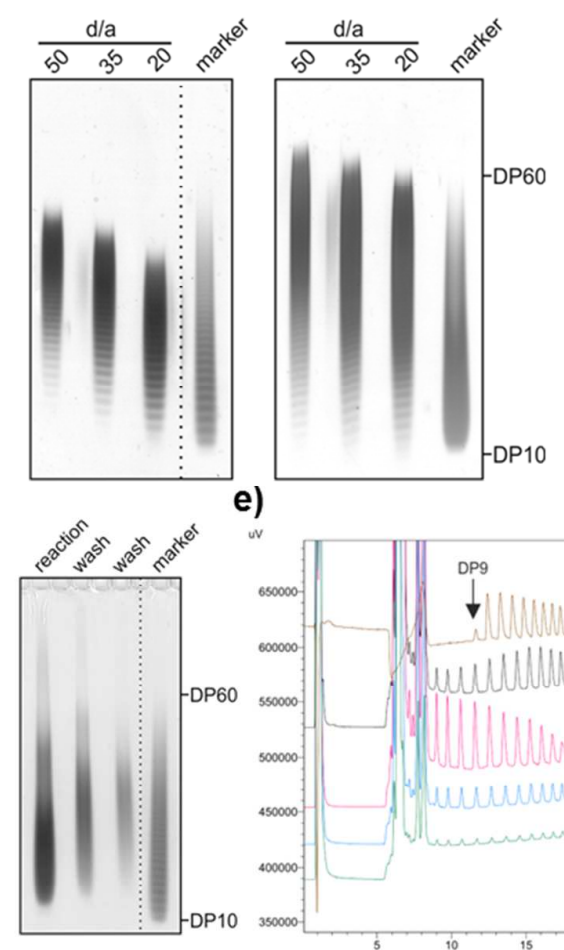

b)

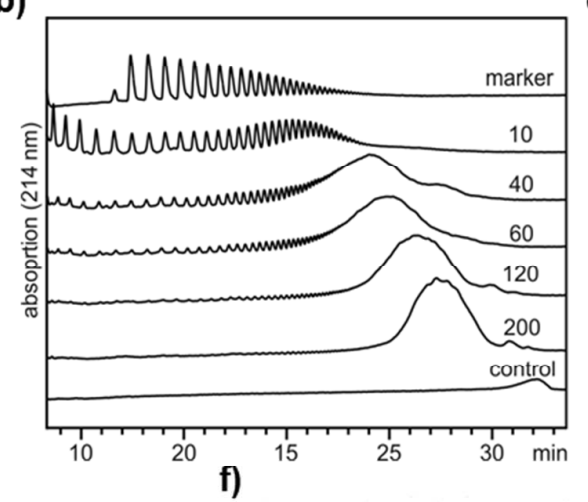

c)

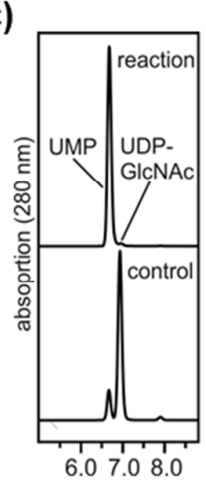

g)

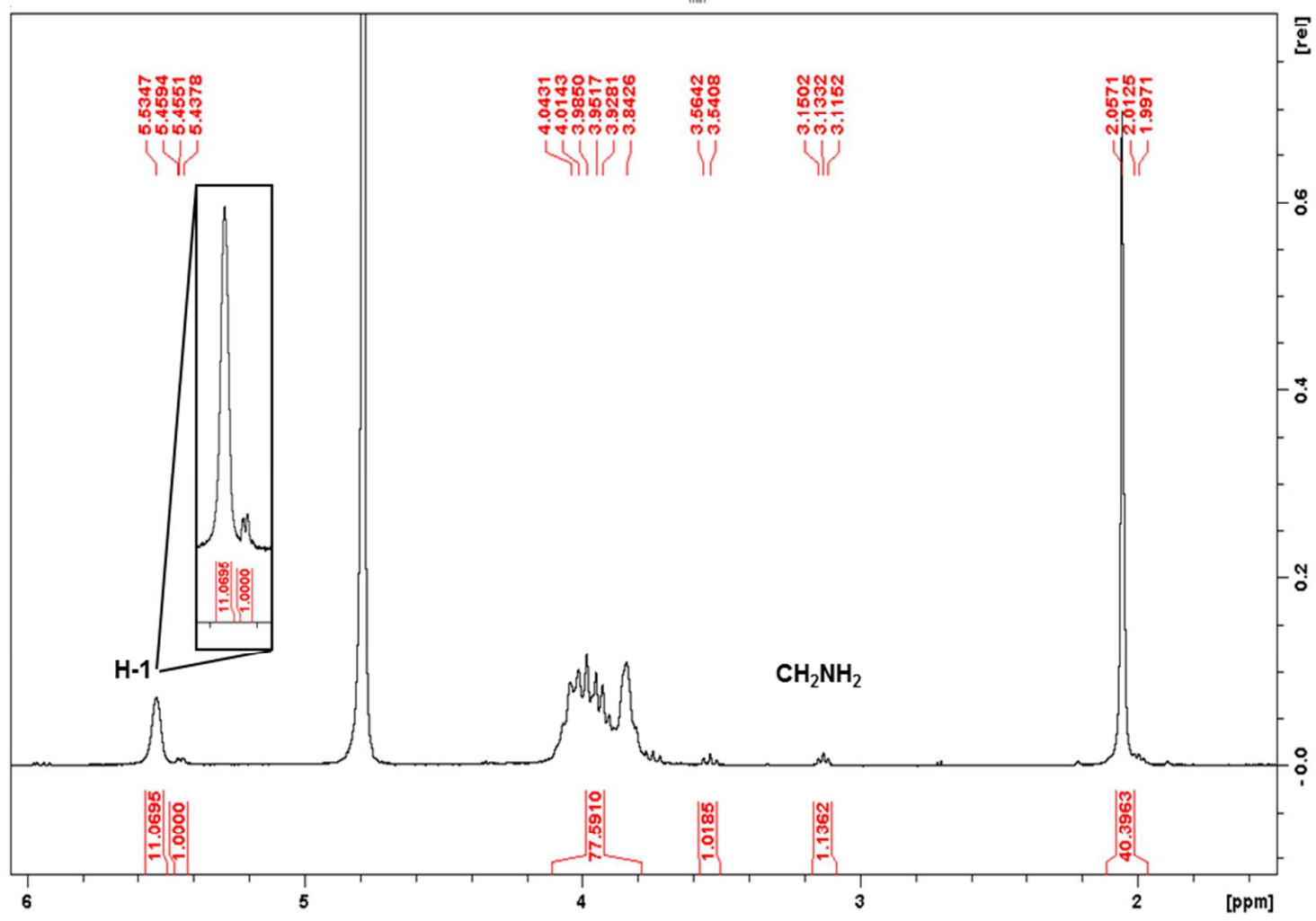

Figure 3. (A) Elongation of DP2-10 acceptor by $\triangle \mathrm{N} 58 \Delta \mathrm{C} 98$-CsxA (left) and $\Delta \mathrm{C} 98$-CsxA (right) at different donor/acceptor $(\mathrm{d} / \mathrm{a})$ ratios. (B) HPLC-AEC $(214 \mathrm{~nm})$ of synthetic DP3 elongated by $\triangle N 58 \Delta \mathrm{C} 98$-CsxA at the indicated d/a ratios. (C) HPLC-AEC $(280 \mathrm{~nm})$ demonstrates that the donor sugar UDP-GlcNAc is completely converted to UMP in a representative trimer elongation reaction. A reaction in the absence of acceptor was used as control. (D) Alcian blue/silver stained gel showing the reaction products after one column passage and two wash fractions in comparison to the marker avDP15. The gel shows an almost 
overlapping profile between the targeted length and the formed oligomer after one column passage. (E) HPLC-AEC $(214 \mathrm{~nm})$ showing the reaction mixture after one column passage, two wash fractions and all fractions pooled (pool pre MonoQ) in comparison to avDP15 marker material. (F) Preparative AEC (MonoQ) was used to separate UMP from the pool. Calibration of the column using DPs of known size enabled the removal of DPs $<9$ to allow a maximal resemblance of the pooled fraction (pool post MonoQ) to the marker material. (G) ${ }^{1} \mathrm{H}$ NMR spectrum $\left(400 \mathrm{MHz}, \mathrm{D}_{2} \mathrm{O}, 25^{\circ} \mathrm{C}\right)$ of the final product (pool post MonoQ) indicating an avDP of 12 .

\section{MenX oligosaccharide production}

During the last years, on-column enzyme immobilization came out as a novel tool to reduce the high cost of enzyme production ${ }^{36}$. The main advantage of immobilized enzymes is the possibility to recover it at the end of the reaction for re-utilization and, consequently, an easier purification of the products from residual enzyme ${ }^{37}$.

In a previous study, $\Delta \mathrm{N} 58 \Delta \mathrm{C} 98-\mathrm{CsxA}$, a recombinant $\mathrm{N}$ - and C-terminally truncated CsxA construct has already been proven suited for on-column immobilization and tailored synthesis of CPSX oligosaccharides ${ }^{34}$. $\Delta \mathrm{N} 58 \Delta \mathrm{C} 98$-CsxA was reported to be superior to $\Delta \mathrm{C} 98$-CsxA with regard to expression level due to the missing, disordered N-terminal part of the protein, and was therefore chosen also in this study for the solid-phase elongation of the synthetic trimer ${ }^{34}$. First, by STDNMR the binding of MenX fragments with $\Delta$ N58 $\Delta$ C98-CsxA was assessed to be over imposable with that of $\triangle$ C98-CsxA (Figure S1, Supplemental information). Then, conditions for the elongation were set up on a natural acceptor with DP2-10, monitoring the reaction with the Alcian blue/silver stained PAGE analyses (Figure $3 \mathrm{~A})^{38}$. As previously shown for $\triangle \mathrm{C} 98$-CsxA ${ }^{34}$, the dispersity of the products generated at different donor to acceptor ratios $(\mathrm{d} / \mathrm{a})$ revealed a distributive elongation. Notably, $\Delta \mathrm{N} 58 \Delta \mathrm{C} 98$-CsxA allowed controlling the polymerization up to a size similar to the marker material containing oligomers with DP10-60.

To determine optimal reaction conditions, $\Delta \mathrm{N} 58 \Delta \mathrm{C} 98$-CsxA reactions at varying ratios between UDP-GlcNAc $(10 \mathrm{mM})$ and the trimer were performed and the products were analyzed by HPLCAnion Exchange Chromatography (AEC) (Figure 3B). The fact that the chain length of the produced polysaccharides decreases with decreasing UDP-GlcNAc/trimer ratio demonstrates that the linker does not impair the enzymes previously reported distributive elongation mechanism (Figure 3B). Moreover, the high efficacy of the reaction remains unaltered as shown by the complete conversion of UDP-GlcNAc to UMP (Figure 3C).

In a next step, the $\Delta \mathrm{N} 58 \Delta \mathrm{C} 98$-CsxA construct was coupled to a HisTrap column via the C-terminal His6-tag as recently described (Figure 4$)^{34}$. In our previous reports, we showed that $27 \mathrm{mg}$ of dN58dC98-CsxA are purified from $1 \mathrm{~L}$ of expression culture ${ }^{19}$, and $62.5 \mu \mathrm{g}$ or $250 \mu \mathrm{g}$ of enzyme 
are enough to convert $12.4 \mathrm{~mL}$ of reaction mixture (containing $10 \mathrm{mM}$ of UDP-GlcNAc) into the final product in an overnight or $4 \mathrm{~h}$ reaction ${ }^{21}$, respectively. In order to ensure the highest degree of conversion of the synthetic acceptor into the target oligomer in one column passage, we decided to load $100 \mathrm{~mL}$ of expression culture onto the column to transform $1.2 \mathrm{~mL}$ of reaction mixture into product, corresponding to more than a 100 fold excess of enzyme compared to the previous studies. The column was washed with binding buffer before the reaction mixture, containing the synthetic trimer and GlcNAc-UDP, was pumped through once (Figure 3C). According to the preceding tests (Figure 3B), a d/a ratio of $\sim 15: 1$ was selected to target a size of avDP15. One passage through the column was sufficient to convert the acceptor into a product population similar to the target material, as verified by Alcian blue/silver stained PAGE (Figure 3D) and HPLC-AEC (Figure 3E). The material was purified by anion exchange chromatography (MonoQ) using a linear sodium chloride gradient ${ }^{34}$. To allow maximal resemblance to the target material typically used in glycoconjugate preparations $^{20}$ (shown as marker in Figure 3E), only fractions containing DP $>9$ (eluting between $320-550 \mathrm{mM}$ of $\mathrm{NaCl}$ ) were collected, dialyzed and further characterized (Figure 3E-F).

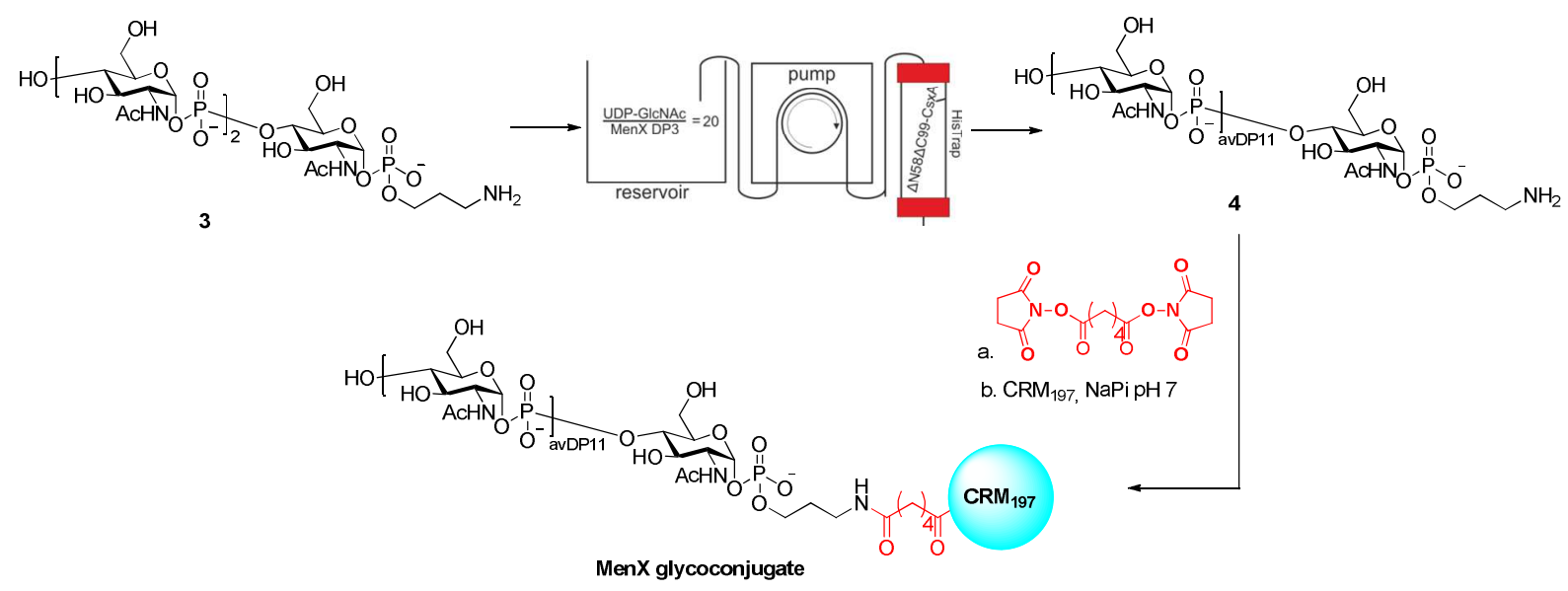

Figure 4. Reactions leading from trimer 3 to MenX glycoconjugate, which include on-column enzymatic elongation using GlcNAc-UDP as donor to give $\mathbf{4}$ and formation of an active ester for protein conjugation.

The average length of the obtained oligomers was established using NMR analysis (Figure 3F and Figure S1 Supplemental information). The ${ }^{1} \mathrm{H}$ NMR clearly showed a ratio of 1:11 between the H-1 of the downstream end modified with the linker, appearing as a doublet of doublets at $5.45 \mathrm{ppm}\left(J_{1,2}\right.$ $=1.4,7.3 \mathrm{~Hz}$ ), and the $\mathrm{H}-1$ of the other anomeric positions at $5.53 \mathrm{ppm}$, indicating that an avDP of 12 was achieved with complete stereochemical control. In addition, the triplet at $3.13 \mathrm{ppm}(J=6.7$ $\mathrm{Hz}$ ) assigned to the $\mathrm{CH}_{2} \mathrm{NH}_{2}$ of the linker unambiguously confirmed the incorporation of the synthetic acceptor in the enzymatically elongated oligomer (Figure 3G). The avDP was confirmed 
in the ${ }^{31} \mathrm{P}$ NMR spectrum of the obtained oligomer by the 1:11 ratio of the linker modified phosphodiester signal compared to the signals of the other interchain phosphodiesters (Figure S3). The discrepancy between the targeted avDP of 15 and the experimentally obtained avDP of 12 indicates that the incorporation of GlcNAc-UDP into the oligomer proceeded with a yield $>80 \%$, when only one passage on the column was applied. Based on the FPLC (Figure 3F) profile the avDP 12 contained a distribution from 9 up to 20 repeating units.

\section{Conjugation to $\mathrm{CRM}_{197}$}

The presence of propyl-amine linker at the reducing end terminus renders the synthesized oligomer ready for conjugation through a reported procedure based on the active ester chemistry (Figure 4$)^{39}$, 40. Briefly, the oligomer was reacted with an excess of the N-hydroxysuccinimidyl adipate in DMSO: $\mathrm{H}_{2} \mathrm{O}$ containing triethylamine. The half ester, quantitatively obtained by precipitation with ethyl acetate and lyophilization, was then incubated overnight with the $\mathrm{CRM}_{197}$ at a $25: 1$ saccharide/protein molar ratio.

SDS-Page gel electrophoresis showed occurrence of conjugation with no detectable presence of unconjugated $\mathrm{CRM}_{197}$ (Figure 5A). Western blot analysis with anti MenX serum confirmed that the sugar was covalently linked to the protein. 
Table 1. Characteristics of glycoconjugates

\begin{tabular}{cccc}
\hline Glycoconjugate & $\begin{array}{c}\text { Saccharide/protein } \\
\text { (mol/mol) }\end{array}$ & $\begin{array}{c}\text { Saccharide/protein } \\
\text { (w/w) }\end{array}$ & $\begin{array}{c}\text { Conjugation } \\
\text { efficiency (\%) }\end{array}$ \\
\hline $\begin{array}{c}\text { MenX-CRM } \\
\text { chemo- } \\
\text { enzymatic }\end{array}$ & 3.1 & 0.2 & 12 \\
$\begin{array}{c}\text { MenX-CRM } \\
\text { enzymatic }\end{array}$ & 3.2 & 0.2 & 32 \\
$\begin{array}{c}\text { MenX-CRM } \\
\text { bacterial derived }\end{array}$ & 4.1 & 0.3 & 34 \\
\hline
\end{tabular}

A $\mathrm{m} \quad \mathrm{CRM}_{197} 1 \mathrm{1} \quad 2 \quad 3$

B
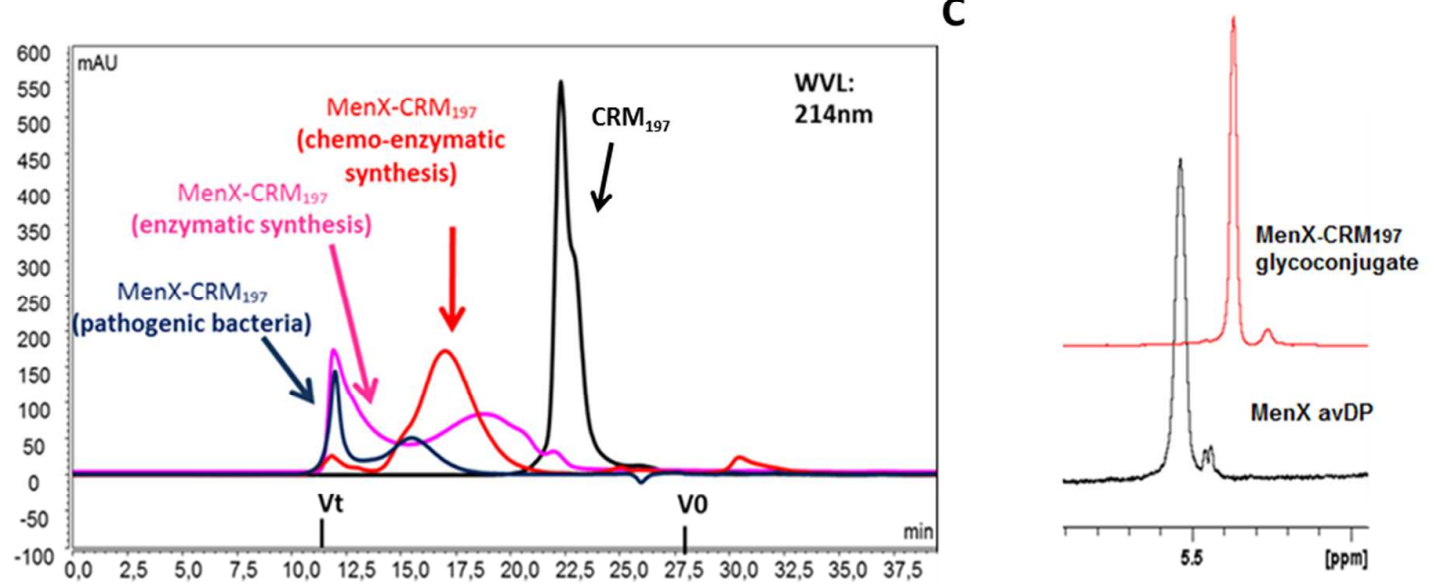

Figure 5. Characterization of the glycoconjugates: (A) SDS-PAGE gel electrophoresis and Western-Blot analysis of the generated glycoconjugate in comparison to the two previously reported controls ${ }^{15,21}$. (B) HPLC profile of the conjugates in size exclusion chromatography using absorption at $214 \mathrm{~nm}$ for detection. (C) Zoom of the $\mathrm{H}-1$ signals of MenX oligosaccharide detected at ${ }^{1} \mathrm{H}$ NMR before $\left(400 \mathrm{MHz}, \mathrm{D}_{2} \mathrm{O}\right)$ and after conjugation $\left(600 \mathrm{MHz}, \mathrm{D}_{2} \mathrm{O}\right)$.

The formed glycoconjugate was purified by precipitation with ammonium sulfate, and characterized by microBCA and anion-exchange chromatography with pulsed amperometric detection (HPAECPAD) analyses for quantification of the protein and saccharide components respectively. The final product was characterized by a $0.2 \mathrm{w} / \mathrm{w}$ saccharide to protein ratio, corresponding to a $3.1 \mathrm{~mol} / \mathrm{mol}$ ratio, that was similar to the conjugates previously reported (Table 1$)^{15,21}$. The resulting conjugation efficiency of $12 \%$, however, was lower than that achieved for the other MenX glycoconjugates (3234\%), where a 10-12:1 saccharide:protein ratio was used at higher protein concentrations. At the applied protein concentration $(\sim 5 \mathrm{mg} / \mathrm{mL})$ an efficiency ranging from 20 to $50 \%$ has been achieved for a number of glycans ${ }^{39,40}$, and a glycosylation level similar to that obtained in this work has been reached also with lower (10-15:1) saccharide:protein ratios ${ }^{41}$. This suggests that scale up of the process under more concentrated conditions could improve the conjugation efficiency, minimizing the hydrolysis of the active ester which is in competition with the amide formation.

The HPLC size exclusion chromatography profile of the purified glycoconjugate showed a peak at lower retention time than the unconjugated protein and with a more homogeneous profile in 
comparison with our previously produced glycoconjugates, presumably as result of the more defined length selected for conjugation and lower occurrence of cross linking in the coupling step (Figure 5B).

Moreover, ${ }^{1} \mathrm{H}$ NMR of the final glycoconjugate showed 1:11 ratio between $\mathrm{H}-1$ of the modified downstream end and the $\mathrm{H}-1$ of the other anomeric positions, comparable to the one of the starting oligomer (Figure 5C and Figure S2 Supplemental information). This result indicated that there was no discrimination of oligosaccharide lengths during the conjugation reaction.

\section{Immunogenicity in mice}

To test the immunogenicity of the novel glycoconjugate vaccine, a mouse immunization study was carried out. For this purpose, $1 \mu \mathrm{g}$ saccharide dose was injected subcutaneously to eight female BALB/c mice (5-6 wk old) per group. Two positive controls were used in this experiment: a conjugate of MenX oligomers obtained from pathogenic bacteria (avDP15-20) and a conjugate prepared by enzymatic elongation of an acceptor produced from polysaccharide sizing (avDP10).

Three immunizations were conducted with two week intervals, whereby the vaccines were formulated in phosphate buffered saline, $\mathrm{pH} 7.2$, in the presence of aluminum phosphate as adjuvant. After the second and third vaccination, anti MenX IgG levels were measured by ELISA. CPSX-CRM $_{197}$ glycoconjugate induced an immunogenic response comparable to the positive control with a significant booster effect after the third dose (Figure 6).

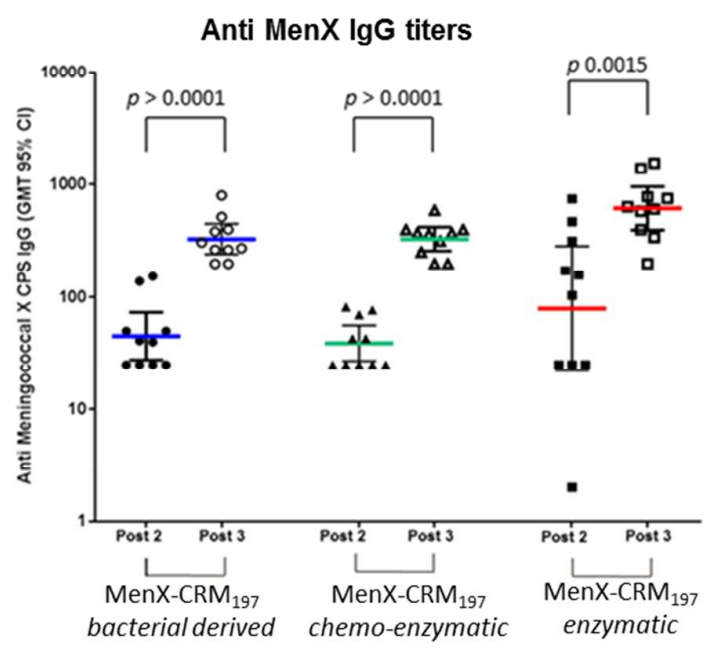

Table 2. Serum Bactericidal Assay

\begin{tabular}{|c|c|}
\hline Glycoconjugate & SBA Titers \\
\hline $\begin{array}{c}\text { MenX-CRM } \\
\text { bacterial derived }\end{array}$ & 8192 \\
\hline $\begin{array}{c}\text { MenX-CRM } \\
\text { chemo-enzymatic }\end{array}$ & 4096 \\
\hline $\begin{array}{l}\text { MenX-CRM }_{197} \\
\text { enzymatic }\end{array}$ & 4096 \\
\hline
\end{tabular}

Figure 6. (A) Anti-MenX IgG ELISA titers after the second and third dose of glycoconjugates, using CPSX for coating. Each dot represents an individual animal. The horizontal bars indicate the geometric mean titer and $95 \%$ confidence intervals. Statistical analysis between the indicated groups was performed according to Mann-Whitney test; SBA mediated by rabbit complement on pooled sera are shown in Table 2. 
The functional activity of the elicited antibodies against MenX strain after the third immunization was evaluated determining the complement mediated bactericidal activity of the sera (Table 2$)^{15}$. Rabbit serum was used as complement source. The pooled serum obtained after immunization with the chemo-enzymatically synthesized hapten showed a strong bactericidal activity (4096) against MenX. This bactericidal effect was comparable to the previously reported effects induced with the control glycoconjugates (8192 and 4096 for the glycoconjugate composed of polysaccharide from the pathogen and from in vitro polymerization of a pathogenic derived acceptor, respectively $)^{15,21}$.

\section{Conclusions}

Possible emergence of $N$. meningitidis serogroup $\mathrm{X}$ in Africa renders urgent the development of a conjugate vaccine. Methods for fast, pathogen free production of the vaccine are desirable. Here we describe a simple on-column procedure for the total synthesis of tailored and ready for coupling MenX fragments. Starting with a functionalized synthetic trisaccharide acceptor and GlcNAc-UDP as donor, the engineered capsule polymerase CsxA delivered oligomers with defined average length, bearing at the downstream end a linker for conjugation to the carrier protein.

By qualitative mapping of the interactions between the enzyme and the trisaccharide with STDNMR, we demonstrated that the short synthetic molecule was engaged by the $\mathrm{N}$-terminal portion of the polymerase $(\triangle \mathrm{C} 98-\mathrm{CsxA})$ similarly to a longer fragment obtained by sizing of the natural polymer. This portion is responsible for the distributive elongation mechanism. The optimized construct $\Delta \mathrm{N} 58 \Delta \mathrm{C} 98-\mathrm{Csx}$ was then immobilized on-column and utilized for controlled elongation of the synthetic trisaccharide up to an avDP12. The produced oligomer was conjugated to the carrier protein $\mathrm{CRM}_{197}$ and tested in a mouse animal model resulting in strong production of bactericidal antibodies.

The production of oligosaccharides composed of repeating units linked to each other through phosphodiester bonds for vaccine manufacturing has been shown feasible by chemical methods, such as polyconsensation via $\mathrm{H}$-phosphonate intermediates ${ }^{42}$. These approaches present some important drawbacks: during the polycondensation reaction the formation of a linear product is in competition with cyclization ${ }^{43}$; the control of the stereochemistry is challenging when 1,2-cis bonds are formed ${ }^{16}$; finally the yield in the generation of phoshodiester bridges in some cases has been observed to decrease at the increase of the length ${ }^{44}$.

The described technology in a simple and cost efficient way generates fully synthetic oligosaccharide antigens with controlled average length, thus avoiding the dangerous handling of pathogens. Compared to conventional synthetic protocols, the number of steps needed to obtain the oligomers in stereoselective manner are remarkably reduced. Furthermore, the presence of a linker 
for conjugation in the synthetic acceptor minimizes the manipulations on the enzymatically produced glycan, such as hydrolysis, sizing and reductive amination steps, which are typically needed before coupling to a carrier protein. A variety of enzymes involved in bacterial capsular biosynthesis are $\mathrm{known}^{45,46}$ and enzymatic in vitro elongation has been shown feasible for both homopolymers $^{27,47}$ and heteropolymers ${ }^{44}$ from different meningococcal serogroups. Therefore this approach is in principle applicable for the preparation of a number of glycans currently used to produce vaccines against bacteria and other pathogens.

There are reports highlighting that small well-defined synthetic carbohydrate epitopes selected on the basis of their binding with protective antibodies are sufficient to elicit a robust immune response in an animal model ${ }^{24,48,49}$. In absence of structural information on the polysaccharide antigenic determinant, the described approach provided oligomers with a distribution optimized to induce a protective immune response comparable to longer structures and higher than the trimer and tetramer so far reported, indicating that relevant polysaccharide epitopes are fully covered.

Along with one-pot/automated solid-phase/enzymatic syntheses, this on-column elongation chemoenzymatic synthesis enriches the methods for expeditious construction of complex bacterial carbohydrates. 


\section{Materials and methods}

STD-NMR experiments. NMR experiments were carried out on a Bruker $500 \mathrm{MHz} \mathrm{NMR}$ instrument equipped with a TBI cooled probe at controlled temperature $( \pm 0.1 \mathrm{~K})$. Data acquisition and processing were performed using TOPSPIN 1.3 and 3.1 softwares, respectively. Suppression of water signal was achieved by excitation sculpting ( $2 \mathrm{msec}$ selective square pulse). Proton-Carbon Saccharides resonances were assigned collecting both $1 \mathrm{D}\left({ }^{1} \mathrm{H}\right.$ and $\left.{ }^{13} \mathrm{C}\right)$ and $2 \mathrm{D}$ (COSY, HSQC) experiments, using standard pulse sequences. STD-NMR experiments were acquired with 96 scans over 96 accumulations and spectral width of $6000 \mathrm{~Hz}(12 \mathrm{ppm})$ at $298 \mathrm{~K}$; a saturation transfer of 2/4 sec was applied to enhance the saturation transfer effect, irradiating at a frequency of 8.0 and -2.0 ppm (3 different spectra recorded for each sample). No differences were observed in the STD spectra irradiating at 8.0 or $-2.0 \mathrm{ppm}$ (4000 and $-1000 \mathrm{~Hz}$ respectively) for all samples, confirming that the saturation transfer effect was not irradiation dependent. To avoid pitfalls in the interpretation of STD-NMR spectra, a negative control spectrum was always recorded in absence of enzyme (ligand and buffer) at the very same condition (concentration and $\mathrm{pH}$ ) of the enzymesaccharide samples. The STD negative controls were always subtracted to the relative enzymesaccharide STD spectrum, obtaining the STDD experiments.

For sample preparation, the enzymatic constructs were exchanged in the working buffer (Tris d-11 $50 \mathrm{mM}, 20 \mathrm{mM} \mathrm{MgCl}$, in $\mathrm{D}_{2} \mathrm{O}$ at $\mathrm{pH} 8.0+/-0.1$ ) through $2 \mathrm{~mL}$ Zeba Spin desalting column saturated with 3 cycles of working buffer, enzymes were finally eluted at the same starting concentration of $1 \mathrm{mg} / \mathrm{mL}$. The $100 \%$ of recovery was assessed through microBCA spectrophotometric assay. Trisaccharide acceptor was dissolved in the working buffer too. Ligand (saccharides): enzyme ratios were set from 1:50 up to 1:100 $\mathrm{mol} / \mathrm{mol}$, depending on the sample.

\section{Chemo-enzymatic synthesis of MenX oligosaccharide.}

Small scale reactions (Fig. $3 b$ ) using $\Delta \mathrm{N} 58 \Delta$ C98-CsxA were performed as previously described ${ }^{34}$. Briefly, $50-200 \mathrm{nM}$ of enzyme was incubated in $75 \mu \mathrm{L}$ of reaction buffer (50 mM Tris $\mathrm{pH} 8.0,20$ $\mathrm{mM} \mathrm{MgCl} 2,1 \mathrm{mM}$ DTT) in the presence of $10 \mathrm{mM}$ UDP-GlcNAc and varying concentrations of the synthetic acceptor. Separation of the generated products by HPLC-AEC was performed on a Prominence UFLC-XR (Shimadzu) equipped with a CarboPac PA-100 column $(2$ x $250 \mathrm{~mm}$, ThermoFisher) using an established method $^{47}$.

For solid-phase synthesis, $\Delta \mathrm{N} 58 \Delta \mathrm{C} 98$-CsxA was expressed in M15 (pREP4) over night at $15^{\circ} \mathrm{C}$, as previously described ${ }^{34} .50-100 \mathrm{~mL}$ of expression culture were pelleted, lysed, coupled to a HisTrap (GE Healthcare) column and thoroughly washed with (i) binding buffer (50 mM Tris $\mathrm{pH} 8.0,500$ $\mathrm{mM} \mathrm{NaCl}, 35 \mathrm{mM}$ imidazole, $1 \mathrm{mM}$ DTT) and (ii) equilibration buffer (50 mM Tris $\mathrm{pH}$ 8.0, $1 \mathrm{mM}$ 


\begin{abstract}
Alcian blue/silver PAGE and SDS-PAGE gel electrophoresis. SDS-Page has been performed on pre-casted polyacrylamide gels (NuPAGE Invitrogen) that can be used with different polyacrylamide concentration, from $3-8 \%$ gradient to $7 \%$. The electrophoretic runs have been performed in Tris-Acetate SDS running buffer (NuPAGE Invitrogen) loading 2.5-5 $\mu$ g of protein each sample, using the electrophoretic chamber with a voltage of $150 \mathrm{~V}$ for about 40 minutes. After electrophoretic running, the gel has been washed in $\mathrm{H}_{2} \mathrm{O}$ for 3 times and then with dye comassie.
\end{abstract}

Western Blot analysis. SDS-Page was run as described before. Gel was transferred on cellulose with iBlot gel transfer stacks nitrocellulose kit and washed 5 times with PBS 1x pH 7.2 +0,05\% tween and blocked with PBS 1x pH $7.2+$ BSA 1\%. Pooled serum from MenX-TT conjugate was used as primary antibody (1:500 dilution, $1 \mathrm{~h})$ followed by 5 washes with PBS + tween 0,05\% buffer. Anti-mouse IgG alkaline phosphatase was used as secondary antibody (1:2000 dil., 30min) followed by 5 washes with PBS + tween $0.05 \%$ buffer. Western-Blot was finally developed with AP conjugate substrate kit (BIORAD).

HPAEC-PAD analysis. As previously described ${ }^{50}$, standard samples of MenX PS at five increasing concentrations ranging between 0.2 and $8.0 \mu \mathrm{g} / \mathrm{mL}$ were prepared to build the calibration curve. 
MenX samples were prepared targeting the calibration curve midpoint. The reference and analytical samples were prepared in $2 \mathrm{M}$ trifluoroacetic acid, incubated at $100^{\circ} \mathrm{C}$ for $2.5 \mathrm{~h}$, followed by $30 \mathrm{~min}$ at $4{ }^{\circ} \mathrm{C}$ and finally quenched with $2 \mathrm{M}$ sodium hydroxide. All analytical samples were filtered with $0.45 \mu \mathrm{m}$ Phenex-NY (Phenomenex) filters before analysis. HPAEC-PAD analysis was performed with a Dionex ICS-5000 equipped with a CarboPac PA1 column $(4 \times 250 \mathrm{~mm}$; Dionex $)$ coupled with a PA1 guard to column $(4 \times 50 \mathrm{~mm}$; Dionex). Samples $(50 \mu \mathrm{L}$ injection volume) were run at 1 $\mathrm{mL} / \mathrm{min}$, using isocratic elution with $14 \mathrm{mM} \mathrm{NaOH}$, followed by a washing step with $0.5 \mathrm{M} \mathrm{NaOH}$. In both HPAEC-PAD analyses, the effluent was monitored using an electrochemical detector in the pulse amperometric mode with a gold working electrode and an $\mathrm{Ag} / \mathrm{AgCl}$ reference electrode. $\mathrm{A}$ quadruple-potential waveform for carbohydrates was applied. The resulting chromatographic data were processed using Chromeleon software 6.8 (Dionex). GlcNAc-4-phosphate ${ }^{51}$ concentration were determined and converted in $\mu \mathrm{mol} / \mathrm{mL}$ to estimate the relative $\mathrm{mol} / \mathrm{mol}$ ratio.

Size Exclusion High Performance Liquid Chromatography (SEC-HPLC). SEC-HPLC has been performed on UltiMate 3000 HPLC system (Dionex part of Thermo Fisher Scientific) equipped with a PDA, RF2000 Fluorescence Detector and RI-101 Shodex Detector. Chromatography has been performed in $0.1 \mathrm{M} \mathrm{NaSO}_{4}, 0.1 \mathrm{M} \mathrm{NaPi}, 5 \% \mathrm{CH}_{3} \mathrm{CN}$, pH 7.2 on TSK 3000SWXL (Tosoh Bioscience) analytical column at flow rate of $0.5 \mathrm{ml} / \mathrm{min}$, with $50 \mu \mathrm{L}$ of injection volume loading 15-25 $\mu \mathrm{g}$ of sample in protein content. The resulting chromatographic data were processed using Chromeleon 6.8 software.

Immunization of mice. Protocols were approved by the Italian Ministry of Health (Approval number n. 804/2015-PR). All mice were housed under specific pathogen-free conditions at the GSK Vaccines Animal Resource Center in compliance with the relevant guidelines (Italian Legislative Decree $n$ 26/2014). Three groups of eight female BALB/c mice were immunized by subcutaneous injection of glycoconjugates at $1 \mu \mathrm{g}$ dose in saccharide content using alum phosphate as an adjuvant. Mice received the vaccines at days 1, 14 and 28. Sera were bled at days 0, 27 and 42.

ELISA of sera. Microtiter plates (96 wells, NUNC, Maxisorp) were coated with $100 \mu \mathrm{L}$ of $5 \mu \mathrm{g} / \mathrm{mL}$ of MenX CPS in Phosphate Buffered Saline (PBS) pH 8.2. Plates were incubated overnight at 2$8^{\circ} \mathrm{C}$, washed three times with PBST (0.05\% Tween-20 in PBS pH 7.4) and saturated with 100 $\mu \mathrm{L} /$ well of PBST-B (3\% Bovine Serum Albumin-BSA in PBST) for $60 \mathrm{~min}$ at $37^{\circ} \mathrm{C}$. The plates were then aspirated to remove the solution and re-washed three times with PBST. $200 \mu 1 /$ well of pre-diluted serum (1:25 for pre immune (negative control), 1:100-1:200 for a reference serum and 
Serum bactericidal assay (rSBA). A commercial lot of baby rabbit complement was used as source of active complement. $N$. meningitidis strain was grown overnight on chocolate agar plates at $37^{\circ} \mathrm{C}$ in $5 \% \mathrm{CO}_{2}$. Colonies were inoculated in Mueller-Hinton broth, containing $0.25 \%$ glucose to reach an OD600 of 0.05-0.08 and incubated at $37^{\circ} \mathrm{C}$ with shaking. When bacterial suspension reached OD600 of 0.25-0.27, bacteria were diluted in the assay buffer (Dulbecco's PhosphateBuffered Saline, DPBS) with $\mathrm{MgCl}_{2}$ and $\mathrm{CaCl}_{2}$ with $1 \% \mathrm{BSA}$ ) at the working dilution (ca. $10^{4}$ $\mathrm{CFU} / \mathrm{mL}$ ). The total volume in each well was $50 \mu \mathrm{L}$ with $25 \mu \mathrm{L}$ of serial two-fold dilutions of the test serum, $12.5 \mu \mathrm{L}$ of bacteria at the working dilution and $12.5 \mu \mathrm{L}$ of baby rabbit complement. All sera to test were heat-inactivated for 30 minutes at $56^{\circ} \mathrm{C}$. Negative controls included bacteria incubated, separately, with the complement serum without the test serum and with test sera and the heat-inactivated complement. Immediately after the addition of the baby rabbit complement, negative controls were plated on Mueller-Hinton agar plates (time 0). Plates were incubated for 1 hour at $37^{\circ} \mathrm{C}$, then each sample was spotted in duplicate on Mueller-Hinton agar plates (time 1). Agar plates were incubated overnight at $37^{\circ} \mathrm{C}$ and the colonies corresponding to time 0 and time 1 (surviving bacteria) were counted. The serum bactericidal titer was defined as the serum dilution resulting in $50 \%$ decrease in colony forming units (CFU) per $\mathrm{mL}$, after $60 \mathrm{~min}$ incubation of bacteria in the reaction mixture, compared to control CFU per $\mathrm{mL}$ at time 0 . The reference strain meningococcal serotype X was Z9615.

\section{Supporting Information}


The Supporting Information, including additional STD NMR spectra and characterization of the synthesized MenX oligomer, is available free of charge on the ACS Publications website.

\section{References}

1. Boisier, P., Nicolas, P., Djibo, S., Taha, M. K., Jeanne, I., Mainassara, H. B., Tenebray, B., Kairo, K. K., Giorgini, D., and Chanteau, S. (2007) Meningococcal meningitis: unprecedented incidence of serogroup Xrelated cases in 2006 in Niger, Clin. Infect. Dis. 44, 657-663.

2. Mutonga, D. M., Pimentel, G., Muindi, J., Nzioka, C., Mutiso, J., Klena, J. D., Morcos, M., Ogaro, T., Materu, S., Tetteh, C., Messonnier, N. E., Breiman, R. F., and Feikin, a. D. R. (2009) Epidemiology and risk factors for serogroup X meningococcal meningitis during an outbreak in Western Kenya, 2005-2006, Am. $J$. Trop. Med. Hyg. 80, 619-624.

3. Delrieu, I., Yaro, S., Tamekloe, T. A., Njanpop-Lafourcade, B. M., Tall, H., Jaillard, P., Ouedraogo, M. S., Badziklou, K., Sanou, O., Drabo, A., Gessner, B. D., Kambou, J. L., and Mueller, J. E. (2011) Emergence of epidemic Neisseria meningitidis serogroup X meningitis in Togo and Burkina Faso, PLoS One 6, e19513. 4. Castillo, C. M. d., Vazquez, J. A., Romero, J., and Pascual, A. (2003) Infections by Neisseria meningitidis serogroup X in Spain, Clin. Microbiol. Infect. 9, 964-965.

5. Chen, C., and Huang, Y. (2008) A first meningococcal meningitis case caused by serogroup X Neisseria meningitidis strains in China, Chin. Med. J. 7, 664-666.

6. Costantino, P., Rappuoli, R., and Berti, F. (2011) The design of semi-synthetic and synthetic glycoconjugate vaccines, Expert Opin. Drug Discov. 6, 1045-1066.

7. Delea, T. E., Weycker, D., Atwood, M., Neame, D., Alvarez, F. P., Forget, E., Langley, J. M., and Chit, A. (2017) Cost-effectiveness of alternate strategies for childhood immunization against meningococcal disease with monovalent and quadrivalent conjugate vaccines in Canada, PLoS One 12, e0175721.

8. Stephens, D. S., Greenwood, B., and Brandtzaeg, P. (2007) Epidemic meningitis, meningococcaemia, and Neisseria meningitidis, Lancet 369, 2196-2210.

9. LaForce, M. F., Ravenscroft, N., Djingarey, M., and Viviani, S. (2009) Epidemic meningitis due to Group A Neisseria meningitidis in the African meningitis belt: a persistent problem with an imminent solution, Vaccine 27 Suppl 2, B13-19.

10. Frasch, C. E., Preziosi, M. P., and LaForce, F. M. (2012) Development of a group A meningococcal conjugate vaccine, MenAfriVac(TM), Hum. Vaccin. Immunother. 8, 715-724.

11. Trotter, C. L., Lingani, C., Fernandez, K., Cooper, L. V., Bita, A., Tevi-Benissan, C., Ronveaux, O., Préziosi, M.-P., and Stuart, J. M. (2017) Impact of MenAfriVac in nine countries of the African meningitis belt, 2010-15: an analysis of surveillance data, Lancet Infect. Dis. 17, 867-872.

12. Ni, J. D., Jin, Y. H., Dai, B., Wang, X. P., Liu, D. Q., Chen, X., Zheng, Y., and Ye, D. Q. (2008) Recent epidemiological changes in meningococcal disease may be due to the displacement of serogroup A by serogroup C in Hefei City, China, Postgrad Med J 84, 87-92.

13. Ji, X., Yao, P. P., Zhang, L. Y., Li, Y., Xu, F., Mei, L. L., Zhu, S. R., Zhang, Y. J., Zhu, H. P., and van der Veen, S. (2017) Capsule switching of Neisseria meningitidis sequence type 7 serogroup A to serogroup $\mathrm{X}, J$ Infect. 75, 521-531.

14. La Force, M. (2017) Progress on MenACWYX vaccine: Phase 1 trial results, MRF Conference. , www.meningitis.com.

15. Micoli, F., Romano, M. R., Tontini, M., Cappelletti, E., Gavini, M., Proietti, D., Rondini, S., Swennen, E., Santini, L., Filippini, S., Balocchi, C., Adamo, R., Pluschke, G., Norheim, G., Pollard, A., Saul, A., Rappuoli, R., MacLennan, C. A., Berti, F., and Costantino, P. (2013) Development of a glycoconjugate vaccine to prevent meningitis in Africa caused by meningococcal serogroup X, Proc. Natl. Acad. Sci. U.S.A. 110, 19077-19082.

16. Morelli, L., and Lay, L. (2013) Synthesis of Neisseria meningitidis X capsular polysaccharide fragments, Arkivoc, 166-184.

17. Morelli, L., Cancogni, D., Tontini, M., Nilo, A., Filippini, S., Costantino, P., Romano, M. R., Berti, F., Adamo, R., and Lay, L. (2014) Synthesis and immunological evaluation of protein conjugates of neisseria meningitidis X capsular polysaccharide fragments, Beilstein J. Org. Chem. 10, 2367-2376.

18. Harale, K. R., Dumare, N. B., Singh, D., Misra, A. K., and Chhikara, M. K. (2015) Synthesis of a tetrasaccharide and its glycoconjugate corresponding to the capsular polysaccharide of Neisseria meningitidis serogroup $\mathrm{X}$ and its immunochemical studies, RSC Adv. 5, 41332-41340. 
19. Fiebig, T., Berti, F., Freiberger, F., Pinto, V., Claus, H., Romano, M. R., Proietti, D., Brogioni, B., Stummeyer, K., Berger, M., Vogel, U., Costantino, P., and Gerardy-Schahn, R. (2014) Functional expression of the capsule polymerase of Neisseria meningitidis serogroup $\mathrm{X}$ : a new perspective for vaccine development, Glycobiology 24, 150-158.

20. Broker, M., Dull, P. M., Rappuoli, R., and Costantino, P. (2009) Chemistry of a new investigational quadrivalent meningococcal conjugate vaccine that is immunogenic at all ages, Vaccine 27, 5574-5580.

21. Fiebig, T., Romano, M. R., Oldrini, D., Adamo, R., Tontini, M., Brogioni, B., Santini, L., Berger, M., Costantino, P., Berti, F., and Gerardy-Schahn, R. (2016) An efficient cell free enzyme-based total synthesis of a meningococcal vaccine candidate, npj Vaccines 1, 16017.

22. Seeberger, P. H. (2015) The logic of automated glycan assembly, Acc Chem Res 48, 1450-1463.

23. Hahm, H. S., Schlegel, M. K., Hurevich, M., Eller, S., Schuhmacher, F., Hofmann, J., Pagel, K., and Seeberger, P. H. (2017) Automated glycan assembly using the Glyconeer 2.1 synthesizer, Proc. Natl. Acad. Sci. U.S.A. 114, E3385-E3389.

24. Schumann, B., Hahm, H. S., Parameswarappa, S., G. , Reppe, K., Wahlbrink, A., Govindan, S., Kaplone, P., Pirofski, L.-a., Witzenrath, M., Anish, C., Pereira, C. L., and Seeberger, P. H. (2017) A semisynthetic Streptococcus pneumoniae serotype 8 glycoconjugate vaccine, Sci. Transl. Med. 9, eaaf5347

25. Classen, T., and Pietruszka, J. (2017) Complex molecules, clever solutions - Enzymatic approaches towards natural product and active agent syntheses, Bioorg Med Chem.

26. Adamo, R. (2017) Advancing homogeneous antimicrobial glycoconjugate vaccines, Acc Chem Res 50, 1270-1279.

27. McCarthy, P. C., Saksena, R., Peterson, D. C., Lee, C. H., An, Y., Cipollo, J. F., and Vann, W. F. (2013) Chemoenzymatic synthesis of immunogenic meningococcal group $\mathrm{C}$ polysialic acid-tetanus Hc fragment glycoconjugates, Glycoconj. J. 30, 857-870.

28. Li, L., Liu, Y., Ma, C., Qu, J., Calderon, A. D., Wu, B., Wei, N., Wang, X., Guo, Y., Xiao, Z., Song, J., Sugiarto, G., Li, Y., Yu, H., Chen, X., and Wang, P. G. (2015) Efficient Chemoenzymatic Synthesis of an Nglycan Isomer Library, Chem. Sci. 6, 5652-5661.

29. Wang, Z., Chinoy, Z. S., Ambre, S. G., Peng, W., McBride, R., de Vries, R. P., Glushka, J., Paulson, J. C., and Boons, G. J. (2013) A general strategy for the chemoenzymatic synthesis of asymmetrically branched N-glycans, Science 341, 379-383.

30. Yan, F., Wakarchuk, W. W., Gilbert, M., Richards, J. C., and Whitfield, D. M. (2000) Polymer-supported and chemoenzymatic synthesis of the Neisseria meningitidis pentasaccharide: a methodological comparison, Carbohydr. Res. 328, 3-16.

31. Pozsgay, V., Gaudino, J. , Paulsonb, J. C., and Jennings, H. J. (1991) Chemo-enzymatic synthesis of a branching decasaccharide fragment of the capsular polysaccharide of type III Group B Streptococcus, Bioorg. Med. Chem. Lett. 1, 991-394.

32. Salamone, S., Guerreiro, C., Cambon, E., Andre, I., Remaud-Simeon, M., and Mulard, L. A. (2015) Programmed chemo-enzymatic synthesis of the oligosaccharide component of a carbohydrate-based antibacterial vaccine candidate, Chem. Commun. 51, 2581-2584.

33. Johnson, K. F. (1999) Synthesis of oligosaccharides by bacterial enzymes, Glycoconjug. J. 16, 141-146. 34. Fiebig, T., Litschko, C., Freiberger, F., Bethe, A., Berger, M., and Gerardy-Schahn, R. (2018) Efficient solid-phase synthesis of meningococcal capsular oligosaccharides enables simple and fast chemoenzymatic vaccine production, J. Biol. Chem.293, 953-962.

35. Costantino, P., Viti, S., Podda, A., Velmonte, M. A., Nencioni, L., and Rappuoli, R. (1992) Development and phase 1 clinical testing of a conjugate vaccine against meningococcus A and C, Vaccine 10, 691-698.

36. Datta, S., Christena, L. R., and Rajaram, Y. R. (2013) Enzyme immobilization: an overview on techniques and support materials, Biotech 3, 1-9.

37. Karav, S., Cohen, J. L., Barile, D., and de Moura Bell, J. M. (2017) Recent advances in immobilization strategies for glycosidases, Biotechnol. Prog. 33, 104-112.

38. Min, H., and Cowman, M. K. (1985) Combined alcian blue and silver staining of glycosaminoglycans in polyacrylamide gels: applicati onto electrophoretic of molecular weight distribution, Anal. Biochem. 155, 275-285.

39. Gao, Q., Tontini, M., Brogioni, G., Nilo, A., Filippini, S., Harfouche, C., Polito, L., Romano, M. R., Costantino, P., Berti, F., Adamo, R., and Lay, L. (2013) Immunoactivity of protein conjugates of carba analogues from Neisseria meningitidis a capsular polysaccharide, ACS Chem. Biol. 8, 2561-2567.

40. Adamo, R., Romano, M. R., Berti, F., Leuzzi, R., Tontini, M., Danieli, E., Cappelletti, E., Cakici, O. S., Swennen, E., Pinto, V., Brogioni, B., Proietti, D., Galeotti, C. L., Lay, L., Monteiro, M. A., Scarselli, M., and 
Costantino, P. (2012) Phosphorylation of the synthetic hexasaccharide repeating unit is essential for the induction of antibodies to Clostridium difficile PSII cell wall polysaccharide, ACS Chem Biol 7, 1420-1428. 41. Tontini, M., Romano, M. R., Proietti, D., Balducci, E., Micoli, F., Balocchi, C., Santini, L., Masignani, V., Berti, F., and Costantino, P. (2016) Preclinical studies on new proteins as carrier for glycoconjugate vaccines, Vaccine 34, 4235-4242.

42. Verez-Bencomo, V., Fernandez-Santana, V., Hardy, E., Toledo, M. E., Rodriguez, M. C., Heynngnezz, L., Rodriguez, A., Baly, A., Herrera, L., Izquierdo, M., Villar, A., Valdes, Y., Cosme, K., Deler, M. L., Montane, M., Garcia, E., Ramos, A., Aguilar, A., Medina, E., Torano, G., Sosa, I., Hernandez, I., Martinez, R., Muzachio, A., Carmenates, A., Costa, L., Cardoso, F., Campa, C., Diaz, M., and Roy, R. (2004) A synthetic conjugate polysaccharide vaccine against Haemophilus influenzae type b, Science 305, 522-525.

43. Nikolaev, A. V., Chudek, J. A., and Ferguson, M. A. J. (1995) The chemical synthesis of Leishmania donovani phosphoglycan via polycondensation of a glycobiosyl hydrogenphosphonate monomer, Carbohydr. Res. 272 179-189.

44. Slattegard, R., Teodorovic, P., Kinfe, H. H., Ravenscroft, N., Gammon, D. W., and Oscarson, S. (2005) Synthesis of structures corresponding to the capsular polysaccharide of Neisseria meningitidis group A, Org Biomol Chem 3, 3782-3787.

45. Litschko, C., Romano, M. R., Pinto, V., Claus, H., Vogel, U., Berti, F., Gerardy-Schahn, R., and Fiebig, T. (2015) The capsule polymerase CslB of Neisseria meningitidis serogroup L catalyzes the synthesis of a complex trimeric repeating unit comprising glycosidic and phosphodiester linkages, J Biol. Chem. 290, 24355-24366.

46. Willis, L. M., and Whitfield, C. (2013) Structure, biosynthesis, and function of bacterial capsular polysaccharides synthesized by ABC transporter-dependent pathways, Carbohydr. Res. 378, 35-44.

47. Fiebig, T., Freiberger, F., Pinto, V., Romano, M. R., Black, A., Litschko, C., Bethe, A., Yashunsky, D., Adamo, R., Nikolaev, A., Berti, F., and Gerardy-Schahn, R. (2014) Molecular cloning and functional characterization of components of the capsule biosynthesis complex of Neisseria meningitidis serogroup A: toward in vitro vaccine production, J. Biol. Chem. 289, 19395-19407.

48. Safari, D., Dekker, H. A., Joosten, J. A., Michalik, D., de Souza, A. C., Adamo, R., Lahmann, M., Sundgren, A., Oscarson, S., Kamerling, J. P., and Snippe, H. (2008) Identification of the smallest structure capable of evoking opsonophagocytic antibodies against Streptococcus pneumoniae type 14, Infect. Immun. 76, 4615-4623.

49. Broecker, F., Hanske, J., Martin, C. E., Baek, J. Y., Wahlbrink, A., Wojcik, F., Hartmann, L., Rademacher, C., Anish, C., and Seeberger, P. H. (2016) Multivalent display of minimal Clostridium difficile glycan epitopes mimics antigenic properties of larger glycans, Nat. Commun. 7, 11224.

50. Micoli, F., Adamo, R., Proietti, D., Gavini, M., Romano, M. R., MacLennan, C. A., Costantino, P., and Berti, F. (2013) Meningococcal X polysaccharide quantification by high-performance anion-exchange chromatography using synthetic N-acetylglucosamine-4-phosphate as standard, Anal Biochem 442, 259-261. 51. Adamo, R., Micoli, F., Proietti, D., and Berti, F. (2014) Efficient synthesis of meningococcal X polysaccharide repeating unit (N-Acetylglucosamine-4-phosphate) as analytical standard for polysaccharide determination, Synth. Commun. 44, 1266-1273.

\section{Author contributions}

LL, RGS, TF, FB and RA conceived and designed the experiments; DO, MRR, TF, DP, MB, MT, LS, LM, RDR performed the experiments; MRR, RGS, TF, FB and RA analyzed the results; DO, TF and RA wrote the manuscript which was reviewed and approved by all the authors.

\section{Notes}

This work was done under a cooperative research and development agreement between Novartis Vaccines and Hannover Medical School; in March 2015 the Novartis non-influenza Vaccines business was acquired by the GSK group of companies which was involved in all stages of the 
study conduct and analysis. DO is a student at the University of Rome and participates in a post graduate studentship program at GSK. LM did a postgraduate internship at Novartis Vaccines. DO, MRR, DP, MT, LS, RDR, FB and RA are employees of the GSK group of companies. TF, MB and RGS are listed as inventors of a patent on the described topic. 


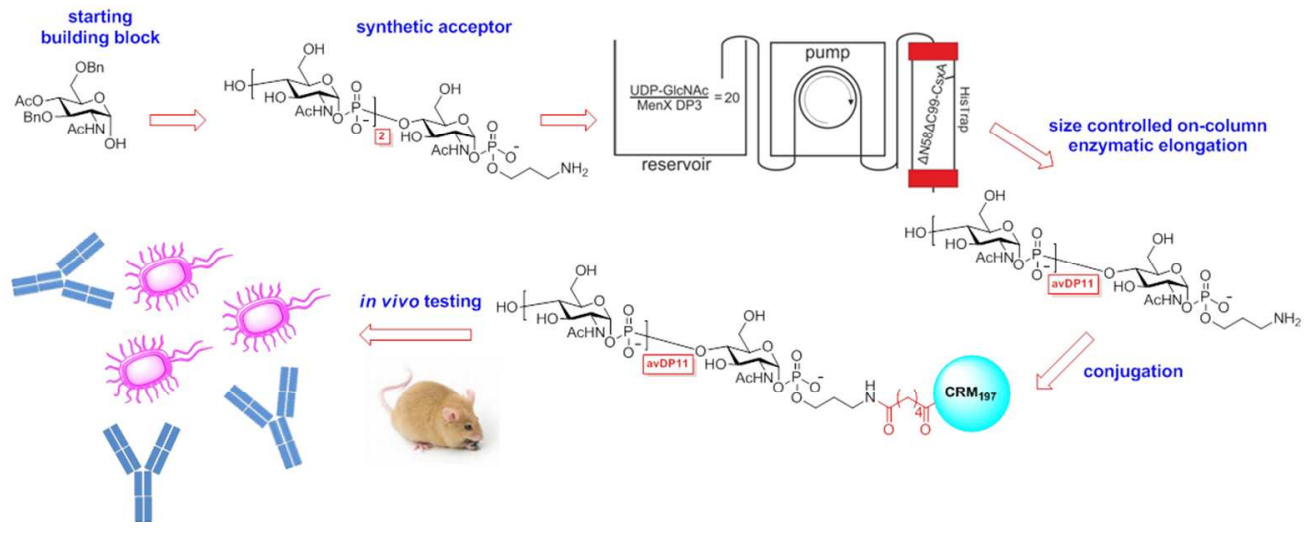

$305 \times 121 \mathrm{~mm}(96 \times 96$ DPI) 